\title{
Culture and Physiological Manipulation of California Strawberries
}

\author{
Victor Voth and Royce S. Bringhurst \\ University of California, Davis, CA 95616
}

After World War II, the California strawberry hectarage increased greatly, reaching a maximum of 8380 ha in 19.57 , with more fruit than the markets could absorb. As a result, within 5 years (1962) the area fell to its lowest post-war point, <2400 ha, and has since increased to 7690 ha in 1989, with increases in total fruit production and yield per unit hectare.

The success of the California strawberry industry has been due to the breeding of a succession of improved cultivars simultaneous with the development of improved planting systems and cultural practices. This paper is concerned with the planting systems, cultural practices, and the physiological manipulation of the California strawberry cultivars. For details on the cultivars, see the cover story.

\section{California planting systems}

Before the modern California planting systems were developed, most plants were transplanted early in the spring and were harvested for 3 to 4 years in southern California and for 4 to 8 years in northern California (then, as now, under the "hill system"). As the plants aged, the fruit size and quality diminished each year until the enterprise was unprofitable. The development of the summer and winter planting systems made it possible to produce and ship fruit of 'Lassen', the original California cultivar adapted to southern coastal California.

Summer planting system. Summer planting, first introduced to growers in southern California in 1955, was a major improvement over spring planting and made annual planting feasible (Voth, 1955).
For this system, plants are dug from Central Valley (near Redding, Red Bluff, and Modesto) nurseries in December or January, when they are as near to dormant as possible and the roots are filled with starch (Bringhurst et al., 1960). Leaves and petioles are removed and the plants are packed in boxes $(30 \times 30 \times 60 \mathrm{~cm})$ that are perforated to permit air exchange and lined with thin polyethylene film to prevent moisture loss. They are then stored below freezing (at -2.2C) until planting time, about 1 Sept., depending on the cultivar and the location of the planting site. They are commonly termed "frigo" plants.

Physiologically, the frigo plants have their chilling requirement fully satisfied (Voth, 1955; Voth and Bringhurst, 1958; Bringhurst et al., 1960) and the plants first go through an abbreviated, nonfruiting first year. The "crown bud" flowers, which were initiated in the nursery in the short-day conditions of the fall, normally are removed and the runners that follow are always removed. The plants are pruned (old leaves are removed) in February and fruit production begins in March or April ( $\approx 7$ months after planting).

This system of annual planting demonstrated that fruit produced by first-fruiting-year plants was larger, firmer, with higher dessert quality and longer shelf life compared to second- or third-year plants (Voth, 1955; Voth and Bringhurst, 1958). Thus, a commercial crop could be realized within 1 year after planting instead of the 1.5 years required for spring planting.

Winter planting system. The practices and principles that have since made winter planting the most important California strawberry 
Table 1. Comparing hours of preharvest freezing and chilling $(<7.2 \mathrm{C})$ temperatures at California high-elevation strawberry nurseries for 1986.

\begin{tabular}{|c|c|c|c|c|c|c|c|c|c|}
\hline \multirow{3}{*}{$\begin{array}{l}\text { Nursery } \\
\text { area }\end{array}$} & \multirow{3}{*}{$\begin{array}{l}\text { North } \\
\text { lat. }\left(^{\circ}\right)\end{array}$} & \multirow{3}{*}{$\begin{array}{l}\text { Altitude } \\
\text { (m) }\end{array}$} & \multicolumn{6}{|c|}{ Hours at given tcmpcrature $\left({ }^{\circ} \mathrm{C}\right)$} & \multirow{3}{*}{$\begin{array}{c}\text { Total } \\
\text { below } 7.2 \\
\end{array}$} \\
\hline & & & \multicolumn{3}{|c|}{ Below 0} & \multicolumn{3}{|c|}{0 to 7.2} & \\
\hline & & & September & October & Total & September & October & Total & \\
\hline Irvine ${ }^{z}$ & 33.8 & 136 & 0 & 0 & 0 & 0 & 0 & 0 & 0 \\
\hline Susanville & 40.4 & 1267 & 21 & 18 & 39 & 196 & 270 & 446 & 505 \\
\hline McArthur & 41.2 & 1013 & 24 & 77 & 101 & 230 & 292 & 522 & 523 \\
\hline MacDoel & 41.8 & 1300 & 78 & 181 & 258 & 259 & 507 & 766 & 1024 \\
\hline
\end{tabular}

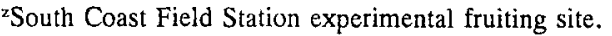

Table 2. Effect of nursery location and soil type on earliness and total 1986 yield of high-elcvation 'Douglas' plants dug 15 Oct. 1985 and planted at the' South Coast Field Station (Irvine) 18 Oct. $1985^{2}$.

\begin{tabular}{lcccccc}
\hline & \multicolumn{9}{c}{ Yield (g/plant) } & Mean berry \\
\cline { 2 - 6 } \multicolumn{1}{c}{ Nursery location } & February & March & Late & Total & SD & \begin{tabular}{c} 
wt \\
\hline MacDoel (sandy, light)
\end{tabular} \\
MacDoel (loamy, heavy) & 197 & 520 & 693 & 1452 & 7 & 20.2 \\
McArthur & 178 & 470 & 667 & 1334 & 41 & 20.1 \\
Susanville & 116 & 317 & 603 & 1167 & 28 & 19.5 \\
\hline
\end{tabular}

${ }^{2}$ Four-row, $1.7-\mathrm{m}$ bed, in-row spacing $30.4 \mathrm{~cm}=75,980$ plants $/$ ha.

'Differences highly significant (ANOVA, $P=0.01$ ).

Table 3. Effect of various polyethylene bed mulches on bed temperatures at $7.6-\mathrm{cm}$ soil depth in winter planting at the South Coast Field Station (Irvine) 1987.

\begin{tabular}{|c|c|c|c|c|}
\hline \multirow[b]{3}{*}{ Mulch } & \multicolumn{3}{|c|}{ Mean bed temp $\left({ }^{\circ} \mathrm{C}\right)$} & \multirow{3}{*}{$\begin{array}{l}\text { Overall } \\
\text { mean }^{z}\end{array}$} \\
\hline & \multicolumn{2}{|c|}{ January-February } & \multirow{2}{*}{$\frac{\text { March }}{\text { pM }}$} & \\
\hline & $\mathrm{AM}$ & PM & & \\
\hline$\overline{\text { Clear }}$ & 8.9 & 25.6 & 31.1 & $21.8 \mathrm{a}$ \\
\hline Brown & 8.3 & 22.2 & 26.1 & $18.9 \mathrm{~b}$ \\
\hline None & 7.5 & 22.7 & 23.9 & $18.0 \mathrm{~b}$ \\
\hline Black & 6.1 & 21.6 & 22.7 & $16.8 \mathrm{c}$ \\
\hline White & 5.0 & 17.8 & 20.0 & $14.3 \mathrm{~d}$ \\
\hline White/Black & 5.5 & 16.6 & 19.5 & $13.8 \mathrm{~d}$ \\
\hline
\end{tabular}

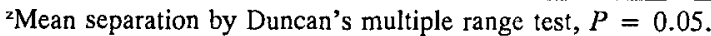

growing system (effectively $100 \%$ from Santa Maria on south and $\approx 50 \%$ in the central coast) were first studied in the late 1950s (Voth and Bringhurst, 1958; Guttridge, 1958; Bringhurst et al., 1960). Included is the use of high-elevation, high-latitude-grown nursery stock, ensuring that the plants receive early nursery chilling (Table 1). Additional cold chamber chilling at 1 to $2 \mathrm{C}$ is given as needed, particularly to-day-neutrals such as 'Selva' (often 3 to 4 weeks), which have a higher chilling requirement than short-day types such as 'Chandler' (usually 0 to 2 weeks; California Strawberry Advisory Board Annual reports, 1985 to 1988). Winter plantings are successful under the relatively warm winter conditions that normally prevail at south-coastal or central-coastal California growing sites only.

Thus, winter planting involves the planting of freshly dug nursery plants that cumulatively have received enough chilling to stimulate sufficient vigorous growth during the short days of winter to produce a good crop of early high quality fruit followed by repetitive fruiting for 6 months or more; hence the name "winter planting". If they lack chilling (vigor), earliness, quality, and total yield are diminished (Table 2).

Note that two plantings of the plants from the coldest nursery (Macdoel) were included in Table 2; plants from a light sandy soil and plants from a heavier (loamy) soil. The latter is more comparable to the McArthur and Susanville soils, although all are light enough to be good nursery soils. The plants from the sandy soil produced fewer plants per hectare, but the plants were about onethird larger with counts of 1000 per standard California box $(30 \times$ $30 \times 60 \mathrm{~cm}$ ), whereas plants from the heavier soil were smaller, averaging $\approx 1.500$ per box. The data (Table 2 ) show that the plants from the colder nursery and from the sandier soil performed best because the nursery plant density was less and, consequently, such plants had larger crowns and root systems.

Historically, after the introduction of 'Fresno' (1961) and 'Tioga' (1964), summer planting became the dominant system statewide. Later, with the introduction of 'Tufts' (1972) and of 'Douglas' (1979), winter planting became the dominant system from Santa Maria and southward to San Diego. At present, only 'Pajaro' (1979 release) and a portion of the 'Selva' (1983 release) hectarage is summer-planted. Growers changed from summer to winter planting because fruit quality is superior (larger, firmer, with better flavor and color) and production commences earlier on winter plantings. In addition, the minimum time from planting to earliest significant harvest on short-day-type cultivars is 3 months for winter plantings, compared with $\approx 7$ months for summer plantings.

Overall quality has improved because the area from San Luis Obispo on south is planted annually and none is carried over for a second year. Similarly, in the Watsonville-Salinas area, only a small percentage is carried over for the second year; plants that are carried over produce the smallest size and poorest-quality fruit in the state.

\section{Polyethylene bed mulch}

Clear polyethylene bed mulch applied very snugly over the soil surface as soon as possible after planting is one of the most useful tools for enhancing the performance of winter-planted strawberries in California. It was first used in 19.58, and the results of early experiments showed increases in earliness and in total yield associated with higher soil temperatures (Voth and Bringhurst, 1959, 1962). It is now standard practice.

Temperatures for six mulch treatments are shown in Table 3 for 1987-88, a fairly typical year, at Irvine (South Coast Field Station); measured in early morning and mid-afternoon, with laboratory thermometers placed $7.6 \mathrm{~cm}$ deep between the plants. Note that the increases in temperatures are directly associated with the amount of radiant energy penetrating the soil; highest for the clear film and lowest for the white over black. The critical temperature for growth in plants, such as strawberries, is $\approx 10 \mathrm{C}$ or above. Black, white, and white/black mulch reduces soil penetration by the sun's rays.

Total yield data for the six strawberry cultivars used in the above 1987-88 experiment are presented in Table 4. While there is some interaction in the response of the various cultivars to the various mulches, the clear mulch unambiguously gave the highest yield in all cases. Clear polyethylene bed mulch is more important during colder winters (Table 5), in large measure due to its effect on earliness. Note the large positive effect of the clear mulch (the warmest 
Table 4. Total 1988 strawberry yield with six kinds of polyethylene bed mulch treatments in a winter planting of high-elevation-grown plants of six cultivars; dug at MacDoel 17 Oct., planted at Irvine 28 Oct. $1987^{z}$

\begin{tabular}{lcccccrr}
\hline & \multicolumn{7}{c}{ Total yield (g/plant) } \\
\cline { 2 - 8 } Mulch & Chandler & C35 & Douglas & Oso & Irvine & Selva & Mean \\
\hline Clear & 1850 & 1655 & 1432 & 1360 & 1238 & 1206 & $1456 \mathrm{a}$ \\
Black & 1397 & 1602 & 1181 & 1101 & 948 & 856 & $1180 \mathrm{~b}$ \\
White/Black & 1397 & 1582 & 876 & 1161 & 1014 & 826 & $1133 \mathrm{~b}$ \\
Brown & 1311 & 1489 & 962 & 1161 & 854 & 830 & $1101 \mathrm{bc}$ \\
White & 1383 & 1332 & 977 & 1091 & 941 & 839 & $1094 \mathrm{c}$ \\
None & 1457 & 1328 & 891 & 1117 & 885 & 747 & $1070 \mathrm{c}$ \\
\hline
\end{tabular}

zTwo-row $1.2-\mathrm{m}$ beds, in-row spacing $41 \mathrm{~cm}=46,131$ plants $/ \mathrm{ha}$.

yMean separation by Duncan's multiple range test, $P=0.05$.

Table 5. Comparison of 1984 strawberry yield and fruit size over six bed mulch treatments in a winter planting of high-elevation 'Douglas' plants; dug at MacDoel 15 Oct., planted at Irvine, 30 Oct. $1983 .^{z, y}$

\begin{tabular}{lccc}
\hline \hline & \multicolumn{2}{c}{ Yield (g/plant) } & \\
\cline { 2 - 3 } Mulch & To & Total & $\begin{array}{c}\text { Mean berry } \\
\text { wt }(\mathrm{g})\end{array}$ \\
\hline Clear & April & $925 \mathrm{a}$ & $22.0 \mathrm{a}$ \\
Reemay-clear & $151 \mathrm{a}$ & $872 \mathrm{ab}$ & $20.6 \mathrm{~b}$ \\
Styrofoam & $132 \mathrm{a}$ & $830 \mathrm{~b}$ & $23.0 \mathrm{a}$ \\
None & $84 \mathrm{~b}$ & $820 \mathrm{~b}$ & $23.6 \mathrm{a}$ \\
Black & $78 \mathrm{~b}$ & $756 \mathrm{bc}$ & $22.8 \mathrm{a}$ \\
White/Black & $79 \mathrm{~b}$ & $739 \mathrm{c}$ & $22.4 \mathrm{a}$ \\
\hline
\end{tabular}

${ }^{2}$ Four-row, $1.7-\mathrm{m}$ bed, in-row spacing $25 \mathrm{~cm}=91,175$ plants/ha.

yMean separation by Duncan's multiple range test, $P=0.05$.

Table 6. Comparison of 1988 yield and fruit size of four strawberry cultivars on two-row and fourrow beds at same plant density $(56,984 / \mathrm{ha})$. Winter planting; dug at MacDoel 15 Oct., planted 26 Oct. 1987 at Irvine. ${ }^{2}$

\begin{tabular}{|c|c|c|c|c|c|c|c|}
\hline \multirow[b]{4}{*}{ Cultivar } & \multicolumn{6}{|c|}{ Type of bed } & \multirow{4}{*}{$\begin{array}{c}\text { Yield } \\
\text { increase } \\
(\%)\end{array}$} \\
\hline & \multicolumn{3}{|c|}{ Twe-row } & \multicolumn{3}{|c|}{ Four-row } & \\
\hline & \multicolumn{2}{|c|}{ Total yield } & \multirow{2}{*}{$\begin{array}{c}\text { Mean } \\
\text { berry wt } \\
\text { (g) }\end{array}$} & \multicolumn{2}{|c|}{ Total yield } & \multirow{2}{*}{$\begin{array}{c}\text { Mean } \\
\text { berry wt } \\
\text { (g) }\end{array}$} & \\
\hline & $\mathrm{g} /$ plant & $\mathrm{SD}$ & & (g/plant) & SD & & \\
\hline Douglas & 1077 & 117 & 17.6 & 1422 & 154 & 18.3 & 32 \\
\hline Chandler & 1519 & 62 & 16.3 & 1827 & 74 & 18.0 & 20 \\
\hline Oso & 1136 & 113 & 18.5 & 1651 & 164 & 20.2 & 45 \\
\hline Irvine & 1088 & 104 & 16.9 & 1281 & 122 & 17.0 & 18 \\
\hline Mean. & 1205 & 99 & 17.3 & 1545 & 128 & 18.4 & 28 \\
\hline
\end{tabular}

${ }^{z}$ Mean difference for total yield is highly significant (ANOVA).

bed) at the same site and the large negative effect of the white/black mulch (the coldest bed) on earliness. In California, growth during November through February accounts for high total yield.

\section{Drip irrigation, bed type, and plant density}

Drip irrigation is extremely important to strawberry production in California for many reasons, including the following: It places water where it is needed without waste and it has made the development of optimum bed shapes, height, and size possible.

The first experiments with drip irrigation on strawberries in California began at Torrey Pines in 1967 with 12.7-mm tubing with an orifice placed every $60 \mathrm{~cm}$. These early experiments showed the benefit of good water placement on the management of salinity, enhancement of production, and reduced water usage (Voth et al., 1973) $)^{6}$. The first true drip systems were developed in 1970 and are in general use now, facilitating all cultural operations.

Drip irrigation permitted development of a new wide four-row bed system that was adopted by southern California growers by 1972 and statewide later. This system increased production per unit area on winter plantings by $30 \%$ to $50 \%$ (Voth et al., 1973).

A recent comparison of the performance of three standard cultivars ('Chandler', 'Douglas', and 'Oso Grande') and one day-neutral ('Irvine') in a winter planting on a two-row, 1.22-m-wide bed with those on a four- row, 1.73-m-wide bed with the plant density constant $(56,984$ plants/ha) is presented in Table 6 . The increase on the four-row-wide bed was greater (45\%) for 'Oso Grande', the cultivar with the largest plants and least (18\%) for 'Irvine', the cultivar with the smallest plants. In all cases there was an increase and the average was $28 \%$.

\section{Fertilizer placement and materials}

Nitrogen fertilization of strawberries is necessary in California. Early experiments with preplant slow-release fertilizers demonstrated their effectiveness, especially as polyethylene bed mulch came into general use (Voth et al., 1963; Voth and Uriu, 1968). The only alternatives are preplant application, placement of slowrelease fertilizers in the planting slot, or application of soluble materials through the drip irrigation lines. Consequently, these systems have been compared experimentally in southern California since 1978 in a soil that is particularly low in nitrogen (Table 7).

The results show that at least double the amount of nitrogen has to be applied through the drip system to compare somewhat favorably with the results obtained from slot applications of slow-release materials at planting.

At the same time, most of the commercially available slow-release materials were compared in a second experiment, overlapping the first in part (controls) (Table 8). 
Table 7. Monthly and total 1987 yield of 'Oso' strawberries irrigated and fertilized with $\mathrm{N}$ through two or four driplines and/or with dry fertilizer applied before planting (slot). Winter-planted MacDoelgrown plants dug 15 Oct. and planted 30 Oct. 1986 at Irvine.

\begin{tabular}{|c|c|c|c|c|c|c|c|c|}
\hline \multirow[b]{3}{*}{ Treatment $^{z}$} & \multirow{3}{*}{$\stackrel{\mathrm{N}}{\left(\mathrm{kg} \cdot \mathrm{ha}^{-1}\right)}$} & \multicolumn{6}{|c|}{ Yield (g/plant) } & \multirow{3}{*}{$\begin{array}{c}\text { Mean berry wt } \\
(\mathrm{g})\end{array}$} \\
\hline & & \multicolumn{4}{|c|}{ Monthly } & \multicolumn{2}{|c|}{ Totaly } & \\
\hline & & March & April & May & June & $g$ & SD & \\
\hline $\begin{array}{l}\text { No } N \text {, control; } \\
\text { two drip lines }\end{array}$ & 0 & 6 & 28 & 37 & 40 & 114 & 11 & 9.3 \\
\hline $\begin{array}{l}\text { Slot AN20; } \\
\text { two drip lines }\end{array}$ & $\begin{array}{l}264 \\
264\end{array}$ & 148 & 571 & 223 & 322 & 1267 & 174 & 22.9 \\
\hline $\begin{array}{l}\text { Preplant AN20; } \\
\text { four drip lines }\end{array}$ & $\begin{array}{l}264 \\
264\end{array}$ & 128 & 704 & 281 & 252 & 1369 & 122 & 24.1 \\
\hline $\begin{array}{l}\text { Slot } 16-20 \text { NS; } \\
\text { two lines AN20 }\end{array}$ & $\begin{array}{l}264 \\
264\end{array}$ & 146 & 666 & 256 & 231 & 1300 & 24 & 23.2 \\
\hline $\begin{array}{l}\text { Preplant drip : } \\
\text { 33.5-0-0 AN; }\end{array}$ & 264 & 159 & 798 & 346 & 155 & 1461 & 191 & 25.8 \\
\hline 16-20 NS & 264 & & & & & & & \\
\hline $\begin{array}{l}\text { Preplant drip } \\
\text { Preplant slot; }\end{array}$ & 132 & 132 & 129 & 876 & 142 & 1494 & 80 & 26.8 \\
\hline $16-20 \mathrm{NS}$ & 264 & & & & & & & \\
\hline
\end{tabular}

${ }^{2} \mathrm{AN}=$ ammonium nitrate, $16-20$; NS = Ammonium phosphate + the nytrapyrin " $\mathrm{N}-S e r v e "$. Fourrow $1.7-\mathrm{m}$ bed, in-row spacing $30 \mathrm{~cm}=75,980$ plants/ha. Split applications of fertilizers as indicated. yExcluding the control (no fertilizer), differences among the treatments are not significant (ANOVA).

Table 8. Monthly and total 1987 yield of 'Oso' strawberries with various slow-release fertilizers. Winter-planted MacDoel plants dug 15 Oct. and planted 30 Oct. 1986 at Irvine.

\begin{tabular}{|c|c|c|c|c|c|c|c|c|c|}
\hline \multirow[b]{3}{*}{ Treatment $^{2}$} & \multicolumn{5}{|c|}{ Yield (g/plant) } & & & & \multirow{3}{*}{$\begin{array}{c}\text { Berry wt } \\
\text { (g) }\end{array}$} \\
\hline & \multirow{2}{*}{$\begin{array}{c}\mathrm{N} \\
\left(\mathrm{kg} \cdot \mathrm{ha}^{-1}\right)\end{array}$} & \multicolumn{4}{|c|}{ Monthly (yield/plant) } & \multicolumn{3}{|c|}{ Total } & \\
\hline & & March & April & May & June & (g/plant) & SD & $\left(\mathrm{t} \cdot \mathrm{ha} \mathrm{a}^{-1}\right)$ & \\
\hline No $\mathrm{N}$, control & 0 & 6 & 28 & 37 & 40 & 114 & 11 & 8 & 9.3 \\
\hline Resin 22-7-10 & 336 & 114 & 653 & 248 & 221 & 1238 & 172 & 89 & 24.5 \\
\hline ES $26-8-8^{y}$ & 336 & 164 & 636 & 221 & 222 & 1246 & 117 & 89 & 24.1 \\
\hline AP $16-20-0$ & 336 & 193 & 640 & 254 & 179 & 1268 & 198 & 90 & 24.3 \\
\hline $\mathrm{AS}+\mathrm{NS} 21-0-0$ & 336 & 148 & 705 & 312 & 193 & 1361 & 28 & 97 & 25.6 \\
\hline Resin AS $18-0-0$ & 336 & 182 & 687 & 285 & 225 & 1382 & 188 & 99 & 24.9 \\
\hline Resin $13-16-0$ & 336 & 169 & 725 & 318 & 187 & 1403 & 85 & 100 & 25.2 \\
\hline ES AS $18-0-0$ & 336 & 176 & 738 & 265 & 235 & 1418 & 139 & 101 & 25.3 \\
\hline 16-20-0 NS slot & 264 & 117 & 876 & 356 & 142 & 1494 & 80 & 107 & 26.8 \\
\hline+ drip line & 132 & & & & & & & & \\
\hline
\end{tabular}

"ES = "Escote", $\mathrm{AP}=$ ammonium phosphate, $\mathrm{AS}+\mathrm{NS}=$ ammonium sulfate + nytrapyrin " $\mathrm{N}$ Serve". 4-row $1.7 \mathrm{~m}$-bed, in-row spacing $30 \mathrm{~cm}=65,127$ plants/ha.

'Excluding the control (no fertilizer), differences among the fertilizer treatments were not significant (ANOVA).

The general conclusion is: Water placement determines fertilizer placement and fertilizer placement is more important than the material used.

\section{CONCLUSION}

While the introdiction of new cultivars accounts for much of the gains that have been made in California strawberry production over the post-World War II years, the improvements in cultural practices, including soil fumigation (not discussed here), have been at least of equal importance. Furthermore, they are so closely linked that one cannot have one without the other.

\section{Literature Cited}

Bringhurst, R.S., V. Voth, and D. Van Hook. 1960. Relationship of root starch content and chilling history to performance of California strawberries. J. Amer. Soc. Hort. Sci. 75:373-381.
Guttridge, C.G. 1958. The effect of winter chilling on the subsequent growth and development of cultivated strawberries. J. Hort. Sci. 33:119-127.

Voth, V. 1955. Stored strawberry plants. Cal. Agr. 9(2):9, 16.

Voth, V. and R.S. Bringhurst. 1959. Polyethylene over strawberries. Calif. Agr. 13(5):5-14

Voth, V. and R.S. Bringhurst. 1962. Early mulched strawberries. Calif. Agr. 16(2):14-15

Voth, V. and R.S. Bringhurst. 1958. Fruiting and vegetative response of Lassen strawberries in southern California as influenced by nursery source, time of planting and plant chilling history. Proc. Amer. Soc. Hort. Sci 72:187-197.

Voth, V. and K. Uriu. 1968. Response of slow release nitrogen materials on California strawberries. Proc. Conf. Efficiency of Nitrogen Usage. 14-15 Dec. p. 22-23.

Voth, V., R.S. Bringhurst, and O.R. Lunt. 1963. Preplant fertilizers on winter planted strawberries. Calif. Agr. 17(10):6-7.

Voth, V., R.S. Bringhurst, H.J. Bowen, and T. Mock. 1973. New strawberry irrigation systems. Calif. Agr. 27(9):8-10. 